\title{
Air Navigation \& Tourism on Trial: Current Controversy into the EU Regulation
}

\author{
F. Javier Heredia Yzquierdo 1* ${ }^{*}$, Antonio Sánchez-Bayón ${ }^{2}$ \\ ${ }^{1}$ Professor Commercial and Corporate Law at EAE Business School (EAE), Madrid, Spain \\ ${ }^{2}$ Professor Legal History and Philosophy \& Comparative Law at Universidad Camilo José Cela, Madrid, Spain; \\ Fellow at EAE, IsPE, Wizner \& co. \\ Email: ${ }^{*}$ javier.heredia@icam.es, ${ }^{*}$ asbayon@ucjc.edu, antonio sanchez bayon@hotmail.com
}

Received 2 March 2015; accepted 23 May 2015; published 26 May 2015

Copyright (C) 2015 by authors and Scientific Research Publishing Inc.

This work is licensed under the Creative Commons Attribution International License (CC BY).

http://creativecommons.org/licenses/by/4.0/

c) (i) Open Access

\begin{abstract}
The aviation industry is a relevant part of the sizable tourism industry. The aviation industry has been growing significantly and become a source of concern for skewing the GHGs policies. The commercial aviation industry is international by its interconnected nature, and it is regulated in an international forum of the UN, the ICAO. The ICAO is taking the climate change problem into consideration but not acting in a specific manner. These factors prompted the EU to incorporate the aviation industry to its ETS. There was a significant international dispute about the matter and currently the situation is on hold. One has to consider the wider ramifications for the global tourism industry.
\end{abstract}

\section{Keywords}

Aviation, Emissions, Growth, International Controversy, Unilateral, Impact, Tourism, Market

\section{Introduction}

This paper serves a) to establish the current controversy regarding the European Union (EU) unilateral action; b) to find the relevance of tourism industry and the relation between aviation and tourism; c) to consider the potential implications of the introduction of the commercial aviation industry into the European trade scheme and its prospective impact on the sizeable tourism industry [1].

The unilateral EU regulation approach: As far as $\mathrm{CO}_{2}$ and greenhouse gas emissions (GHG) are concerned the 1997 Kyoto Protocol (of which the United States is not a Party) is the key milestone that will define the legal

\footnotetext{
${ }^{*}$ Corresponding author.
} 
answer to this issue. At the time the aviation industry was excluded from the control mechanisms of the Protocol. This doesn't mean it was not considered. The Kyoto Protocol mandates the International Civil Aviation Organization (a specialized agency of the United Nations) to address the possibilities of regulating and creating a potential global emissions rights market for the civil aviation sector "The Parties included in Annex I shall pursue limitation or reduction of emissions of greenhouse gases not controlled by the Montreal Protocol from aviation and marine bunker fuels, working through the International Civil Aviation Organization and the International Maritime Organization, respectively" [2].

Since then the International Civil Aviation Organization (ICAO) has been working on the development of international agreements that would help in the major international efforts to tackle climate change. The ICAO has come to declaring the advisability of a regulatory system based on the $\mathrm{CO}_{2}$ trading scheme to the point of stating that "such measures could achieve environmental objectives at lower cost and in a more flexible manner" [3] while asking the States and the Council "to develop this as a priority to establish guidelines for open emissions trading that focuses on the creation of legal and structural basis for participation in an open trading system, and includes key elements such as the report, monitoring and compliance while providing the maximum flexibility within the process of the World Conference of the United Nations Climate Change” [4].

These efforts have continued as seen reflected in the various Assemblies and final conclusions documents produced by the ICAO. As early as 2007 the Agency asks the Council to “continue to explore policy options to limit or reduce the environmental impact of emissions from aircraft engines and develop concrete proposals and provide advice as soon as possible to the Conference of the Parties to the UNFCCC, encompassing technical solutions and market-based measures." [5]. However, neither the Agency nor the United Nations in any of its institutions has been able to achieve and to establish up to the moment a clear global market scheme for the international aviation industry neither voluntary nor compulsory for trading $\mathrm{CO}_{2}$ emissions in any form, even in embryonic form or study phase. This has generated an amount of frustration in some of the most relevant international actor, notably the European Union: “The European Commission ('the Commission'), frustrated with what it saw as a lack of progress at the international level in tackling the growing issue of emissions from aircraft, had the sector in its sights since at least 2005. The EU saw itself as leading the world in tackling climate change impacts and hoped that its approach might become a blueprint for a wider international scheme to tackle the emissions contributed by the aviation sector." [6].

Since 2005 coinciding with the entry into force of the Kyoto Protocol, the policies of the European Union have been showing a strong interest in including the airline industry within its greenhouse gas emissions general regulatory policies. In 2006 the Commission published a first draft directive. This takes into account the work done in parallel by the International Civil Aviation Organization and includes in its final regulation on the issue, Directive 2008/101/EC of 19 November 2008 amending the Directive 2003/87/EC the aviation activities in the Community scheme of allowances for greenhouse gases. This caused international controversy.

Under these Directives and complementary regulation from 1 January 2012 a comprehensive traffic regulation on airline emissions was established. Under these regulations it is expected that all airlines reduce total CO2 emissions from flights landing or departing from European airports. This means that a) airlines are the ones to be deemed accountable for rendering CO2 emissions, and no other relevant parties such as Air Navigation Services Providers, fuel suppliers, aircraft manufacturers or airport operators. All were considered by the Commission under ICAO guidelines [7].

Also, the burden of the clerical work regarding providing emissions relevant data would be placed on the Airlines companies shoulders: "It is therefore recommended that the obligations under the scheme should be applied on the basis of the total aggregated emissions from all covered flights performed by each aircraft operator included in the scheme... It is recommended, however, that aircraft operators ensure appropriate systems for data collection and management prior to implementation of aviation into an emissions trading scheme." [8] and b) a geographical criterion is applied. A criterion based on the location of the airports and not based on the national origin of the airlines. As a report for the European Commission, DG Environment stated: “This study examined whether there are any legal obstacles to the geographical scenarios considered. As was soon apparent, emissions trading are not addressed by the instruments of current international aviation law. Therefore, the main conclusion with regard to legal feasibility is that international provisions such as the Chicago Convention and bilateral agreements contain no obstacles to including aviation's climate change impact in the EU ETS. This conclusion is in respect of the inclusion of all aircraft, irrespective of ownership or country of registration, within the scope of the options that are considered in this study" [9] thus another point of friction in the international controversy: “...unfortunately it seems that the EU is becoming increasingly isolated with most countries forming 
the consensus, steered by the US, that the EU should only regulate the carbon emitted by planes within EU airspace. At first blush the EU only regulating within EU airspace seems reasonable. Until you look at the environmental effects: even if every country in the world accounted for all emissions in their airspace, only $22 \%$ of global aviation emissions would be regulated. This makes sense as think about that fight from Brussels to JFK, most of it is over the high seas-which country is or should be responsible for those emissions?" [10].

It is remarkable to note that this regulation also leans the European greenhouse gas emissions problem towards a cap-and-trade or indirect policies methods versus a more direct political control policies or commandand-control approach. This has found support from the largest trade association representing the aviation industry, the International Air Transport Association (IATA) in a 2004 letter to the then Austrian Foreign Affairs Secretary showing its support for an emission control market policy. In the letter the European Commission market control policy is directly quoted "Similarly, during a Q\&A session with respect to climate change and why the Commission is bringing aviation into the EU ETS, the EU stated that "...Compared with alternatives such as a fuel tax or charge, bringing aviation into the EU ETS provides the same environmental benefit at a lower cost to society - or a higher environmental benefit for the same cost. In other words the impact on ticket prices, airline companies and the overall economy will be smaller for a given environmental improvement." And the letter continues by stating that "... New taxes are clearly not seen as the right way forward at EU/European level. ... This is not the time to add new tax burdens to the aviation industry." [11]. It clearly shows that the IATA is clearly biased towards an indirect-control emissions rights market as means to curve the greenhouse emissions in detriment of a direct tax control or command and control policy.

This view was not necessarily shared by all IATA and ICAO members. Many of them show a clear disagreement with the inclusion of all air navigation sectors in the greenhouse gases emission rights market, as it is generating a situation of international conflict. The mandatory inclusion of all the airline companies in the European scheme and not just the European ones was decided upon in order to avoid a negative discrimination towards the EU Member States companies. The EU Governments have not hesitated into defending their national carriers or local private companies' interests. This is especially the case as the system chosen by the EU (cap-and-trade or market system) is not necessarily the one that has been chosen by other parts of the world in order to produce regulation aimed to curve the greenhouse gas emissions problem. The United States of America, China, and India have chosen to have a voluntary market or not to take any measure at all. These countries have led the legal dispute to the aviation industry inclusion in the European Market Scheme or EMS. A dispute which has not been restricted in the international forums but has also been played our within the European Courts; this will be further discussed in a separate chapter.

Why has the European Union (EU) attention turned into regulating the aviation industry traffic? And why was 2006 the year when it all started? The sheer amount of $\mathrm{CO}_{2}$ emissions from the aviation industry is relevant enough. According to Committee on Climate Change data only in the UK commercial aviation industry was responsible in 2012 of approximately 34 million tonnes (Mt) per annum in 2012. That accounts for The Energy Savings Trust estimate that the average house produces $4.5 \mathrm{t}$ of $\mathrm{CO}_{2}$ per annum so aviation's contribution in that country alone is approximately equivalent to the $\mathrm{CO}_{2}$ generation from 7.7 million homes. More than $\mathrm{CO}_{2}$ emissions coming from shipping or waste origin [12]. If aviation were a country, it would rank as 21 in size by GDP [13]. Size matters, but not only size triggered the EU reaction.

In financial terms, commercial airlines generated combined revenue of around $\$ 717$ billion in 2013 with expected $\$ 751$ b. for 2014 [14]. Those amounts would suggest enough capacity to cover for $\mathrm{CO}_{2}$ emission rights purchases. However, the industry argues these numbers are deceiving. In 2014 they expect profits of only $\$ 6.02$ for every passenger carried [15]. Those meagre results show an industry facing already several problems without the burden that the EU legislation would mean. However it is a much divided industry. Former national carriers now face fierce competition from new players: “... Low-cost carriers, such as South West and Ryanair, introduced cut-throat rivalry on short-haul routes... Meanwhile, a new breed of state airlines, based mainly in the Persian Gulf, has brought more competition for long-haul passengers. Long-established airlines regularly yelp that the Gulf newcomers get state hand-outs in the form of reduced landing fees and subsidised fuel from the governments of Dubai, Qatar and Abu Dhabi, though the charges are largely unwarranted." [16].

Plus, the European Commission was alarmed about the Figures 1-5 showing an exponential growth of $\mathrm{CO}_{2}$. According to some sources, at that time, the growth was $118 \%$ in the US between 1990 and 2006 [17] and up to $80 \%$ globally in the period from the early 1990's to the year 2004 [18].

And if that was the situation in general for the aviation sector the projections were even more alarming. In 


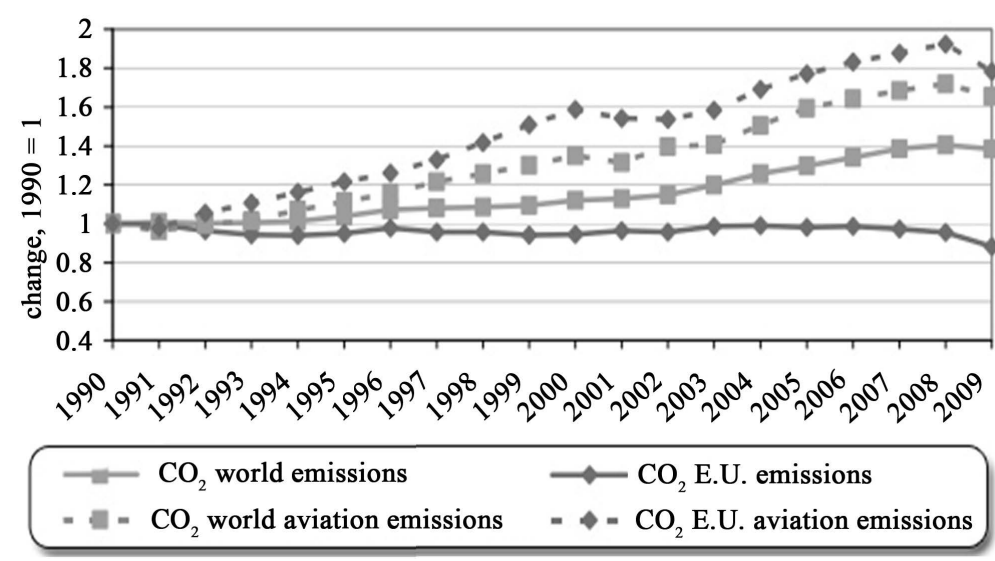

Figure 1. Percent changes in $\mathrm{CO}_{2}$ emissions in the international aviation industry and all the fossil fuels in the EU and in the World [21].

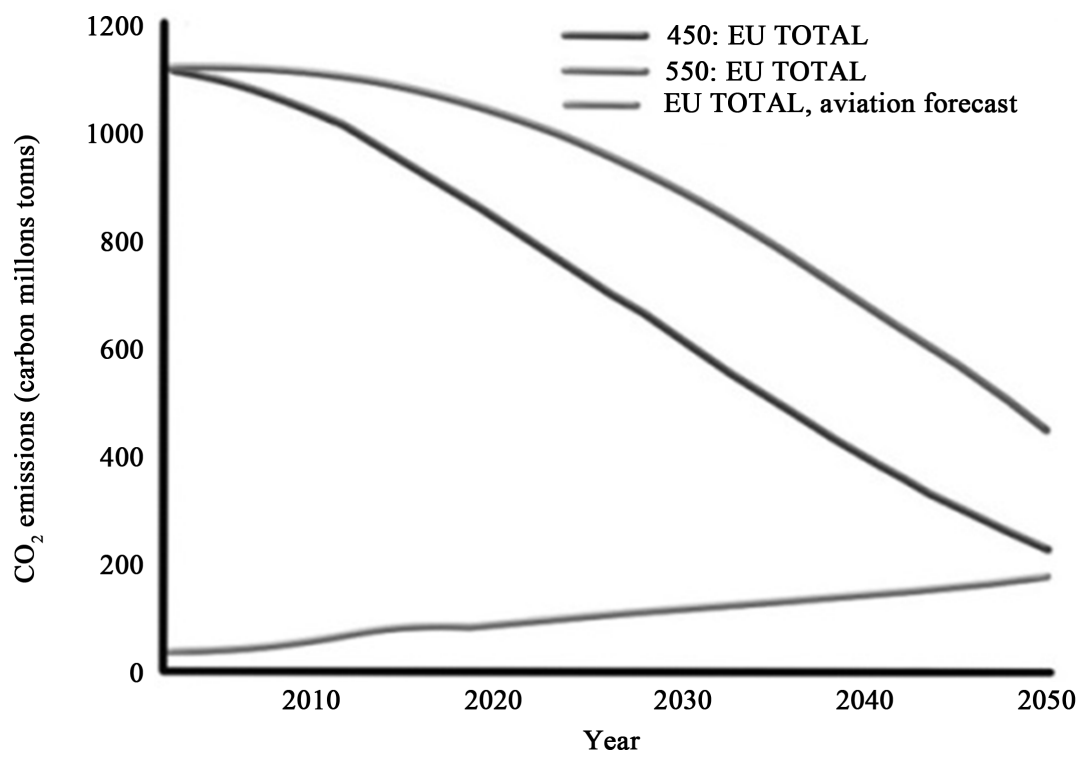

Figure 2. Contraction and convergence profiles for the EU25 compared to the planned issue for aviation [27].

Direct jobs generated by air transport in Europe, 2012

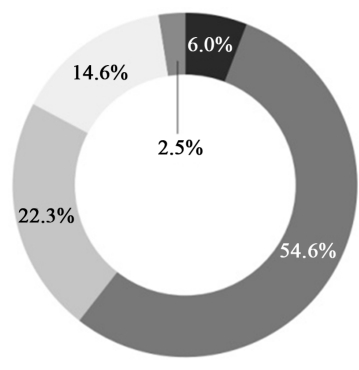

$$
\begin{aligned}
& \text { Airports } \\
& \text { Other on-airport } \\
& \text { Airlines }
\end{aligned}
$$

Europe's share of global passenger traffic, 2012

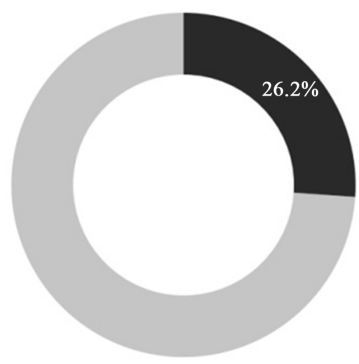

- Europe

Rest of the world
Total jobs and GDP generated by air transport in Europe, 2012

Figure 3. The air transport industry in Europe [32]. 


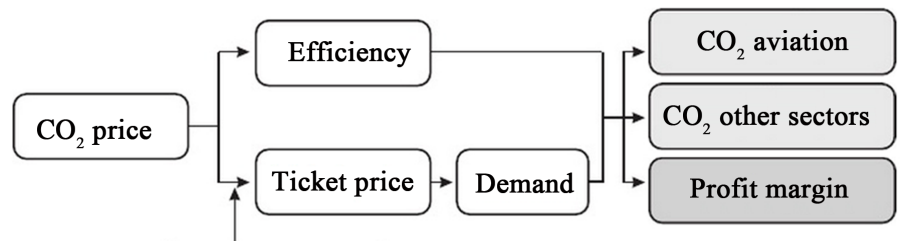

Pass through rate

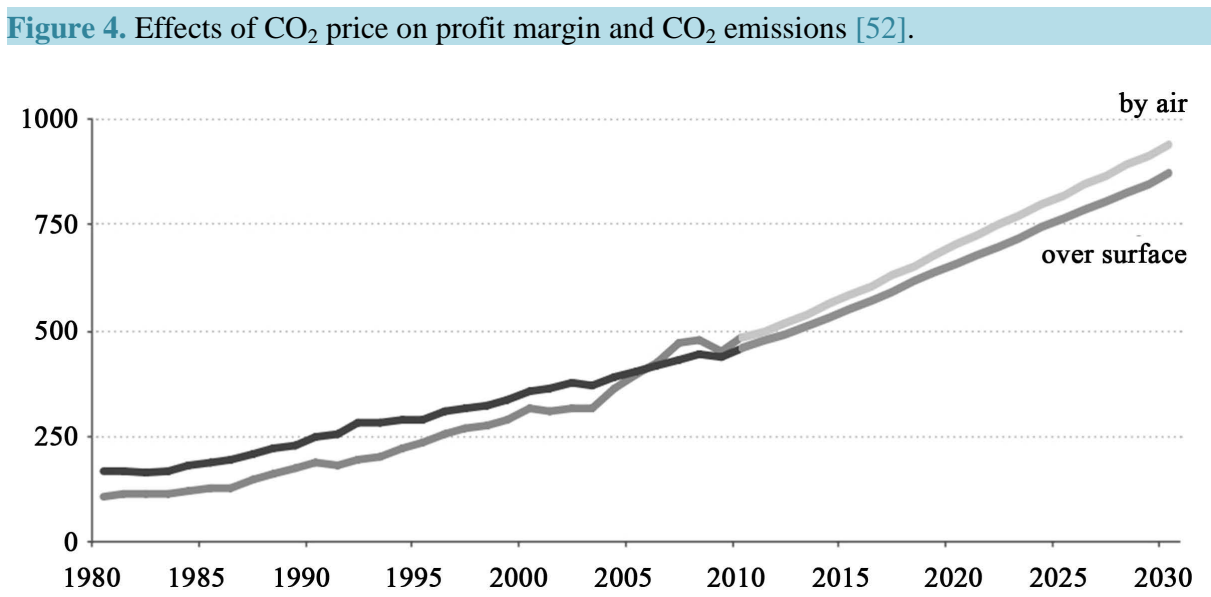

Figure 5. Forecast of international tourist arrivals (millions) [93].

2006 it was argued that the global rates of emission of the air transport industry had shown to be one of the main sources of the general global emissions of fossil fuels increase. As the US Congressional Research Service states "Aviation has been one of the most rapidly growing sources of $\mathrm{CO}_{2}$ emissions... In the EU, fossil fuel emissions fell by about 5\% from 1990 to 2009, while the emissions from aviation fuels sold in the EU rose by about 80\%. This was more than the increase of all emissions from Spain. Globally, also, aviation emissions rose faster than all fossil fuel emissions, though the difference was less. ICAO estimated that $\mathrm{CO}_{2}$ emissions from all aviation (not just international) almost doubled from 1990 to 2006. This compared with a 34\% increase from all fossil fuel use." [19].

Furthermore other authors refer to equally alarming arguments: "Rapidly increasing greenhouse gas emissions from aviation have led to pressure for regulation of the sector's emissions. In the European Union (EU) alone, aviation emissions increased by 94\% between 1990 and 2011, and are expected to rise further. The International Civil Aviation Organisation (ICAO) forecasts that by 2036 global aviation emissions will increase between 155\% and 300\% compared to 2006 levels. Even though new technologies and management techniques have led to considerable improvements in fuel efficiency, and biofuels hold further potential to reduce emissions, their benefits are outstripped by an ever-growing demand for air travel. The overall contribution of aviation to climate change is therefore expected to increase significantly." [20].

Yet this growth is really meagre compared to what is expected for the near future. Some forward-looking experts emphasize the potential exponential growth of these emissions. The prestigious Tyndall Centre for Climate Change Research has estimated a growth of $667 \%$ by 2050 if measures that can mitigate this impact are not taken [22]. This caused alarm bells to ring in Brussels with the foreseeable effect of proceeding to legislate on the subject since it is expected to be impossible for airlines to develop technologies that will improve fuel consumption and pollution in the same proportion as air traffic will grow: "Despite the fact that there are significant opportunities for reducing emissions and other environmental impacts, the RCEP (RCEP, 2002) and the results of this project conclude that their effect is likely to be outstripped by the projected increases in air transport” [23].

Is therefore reasonable that the aviation industry caught the attention of the European Commission up to the degree of regulating it? The transport sector accounts for between $24 \%$ and $28 \%$ of $\mathrm{CO}_{2}$ emissions from energy sources with a forecasted high growth ahead “... like fuel use, emissions $\mathrm{CO}_{2}$ from vehicles is expected to in- 
crease by a factor of 2.4. (i.e. 140\%) ... in 2050” [24] and emissions from commercial aviation industry represents $3.4 \%$ of total $\mathrm{CO}_{2}$ emissions [25]. Given such a low percentage it does not seem unreasonable that the amounts are not what triggered the alarm in the EU capital, but the rapid growth of the sector as has been discussed. And there seems to be additional reasons.

As explained in the renowned Journal of Sustainable Tourism (January 5, 2009) with regard to why this sector is particularly relevant in $\mathrm{CO}_{2}$ emissions: "Within the transport sector, air travel is paramount. First, only a minority ( $>2 \%$ ) of the total world population uses air travel as a means of international transport (estimate based on figures from the World Tourism Organization, 2005). Second, emissions from air travel is particularly damaging as they are released in the upper troposphere and lower stratosphere, where they have a greater impact on cloudiness and ozone generation (Sausen et al., 2005), both of which are important factors contributing to reinforce radioactivity and hence global warming. Emissions from air travel have been confirmed as more harmful to the environment between 1.9 and 5.1 times the surface emissions from traffic... And third, the technological progress in the aviation sector is slow...” [26].

All these facts prompted the European Commission to act regardless potential controversy. The European Commission took the decision to draft the Directive 2008/101/EC of November19 2008, whose casuistry, effects and reactions we discuss below.

You cannot however say that the commercial airline industry had been insensitive to the problem of CO2 emissions. The first regulatory framework for air transport industry dates back to the 1940's. The Chicago Convention on International Civil Aviation signed in 1944 and entered into force in 1947. The purpose was to establish rules regarding international aviation security and rights to the signatories in relation to international air transport. The ratification of the Chicago Convention led to the creation of a specialised unit within the umbrella of the United Nations, the Organization of the International Civil Aviation Organization (ICAO). This agency brings together 191 member states, which works with the major industry associations. The role of ICAO will be extremely relevant, since it is considered by itself in its 36 Assembly as a body responsible for the problem, saying "The Assembly: 1. Declares that ICAO, as the lead United Nations Agency in matters involving international civil aviation, is conscious of and will continue to address the adverse environmental impacts that may be related to civil aviation activity and acknowledges its responsibility and that of its Contracting States to achieve maximum compatibility between the safe and orderly development of civil aviation and the quality of the environment. In carrying out its responsibilities, ICAO and its Contracting States will strive to... c) limit or reduce the impact of aviation greenhouse gas emissions on the global climate;" [28]. In their regard it is the responsibility of the UN to deal with this issue on a global level. This position was maintained over the next two Assemblies, crystallizing up to some extent on the A38 in Montreal and will be to the other non-EU global players when object is sent the EU Directive, as explained in point referred to the controversy over the issue.

Aviation and Tourism: Some basic data shows the amount and relevance of connection between aviation and tourism: “1397 airlines operate a fleet of 25,000 aircraft serving 3864 airports managed by 173 air navigation service providers. Last year, airlines carried 3.1 billion passengers worldwide. More than 58 million people are employed worldwide in aviation and related tourism” [29].

Aviation and tourism have been supportive of each other since commercial aviation activities started in the 1950's. The aviation sector also represents a sizeable percentage of many countries GDPs and supports the tourism industry: "Aviation plays a central role in supporting tourism. Over 52\% of international tourists now travel by air. Tourism is particularly important in many developing countries, where it is a key part of economic development strategies. In Africa, for example, the jobs of an estimated 2.5 million people directly employed in tourism are supported by overseas visitors arriving by air, representing $30 \%$ of all tourism jobs in Africa. In some island states, tourism can have an overwhelming influence on the national economy.” [30].

It is also a fast growing industry. In words of Michael Gill, the Air Transport Action Group (ATAG) Executive Director in Geneva in April 2014: “Tourism is fast becoming the world's number one industry and it is one that aviation is proud to help facilitate. The growth in the middle classes in the emerging economies of the world is being met with a similar boom in air transport, most keenly felt in the Asia-Pacific region" [31]. Only in Europe the impact and size of the aviation industry and tourism are staggering. The aviation industry meaning a 11,727,000 employment impact as tourism catalytic:

Culture and tourism are major drivers in the connectivity: "The pattern and depth of these connections appears to be in part driven by historical and cultural ties, for example the historical connections between Spain and Latin America appear to have played a role in shaping the network of connections available from Madrid 
Barajas (airport).” [33]. It should be underlined that this happening in Spain, which ranked the third most visited country in the world in 2013 after France and the USA [34]. It is not a mere chance that the UN Agency for Tourism, the Word Tourism Organisation, sites in Madrid (Spain, European Union). And they are very aware of the link between tourism, commercial air transport and GHG emissions: "Air passenger transport is closely associated with tourism, which generates a higher contribution of Gross Domestic Product, jobs and investment than most other economic activities; this is particularly the case in developing countries, where tourism is the principal service sector activity. At the same time, air passenger transport is the dominant, and a growing, contributor to global Greenhouse Gases (GHGs) generated by visitors” [35]. It can be therefore inferred the existence of a clear link between the commercial aviation industry, the financial relevance of the tourism industry, especially in the developing countries, and the GHG emissions issue.

\section{Regulation and Lawsuits}

The regulatory standards used with the aviation industry falls within the general regime that dictates the permitted $\mathrm{CO}_{2}$ allowances trading market. This market displays two possibilities: a regulated mandatory regime and a voluntary regime. All regulated regimes have the Kyoto Protocol under the United Nations Convention on Climate Change (UNFCCC) as its source. Its goal is to facilitate the exchange in a regulated market on two fronts, in emission allowances or permits and in credits based on projects.

The emissions trading scheme is firstly enshrined in the Article 17 of the Kyoto Protocol "Article 17: The Conference of the Parties shall define the relevant principles, modalities, rules and guidelines, in particular for verification, reporting and accountability for emissions trading. The Parties included in Annex B may participate in emissions trading for the purposes of fulfilling their commitments under Article 3. Any such trading shall be supplemental to domestic actions for the purpose of meeting quantified emission limitation and reduction commitments under that Article" [36]. And under it, the countries signatories of the Annex 1 also known as the Parties [37] will be allowed to buy and sale allowances through the international emissions trading system. These allowances are known by their acronym as AAUs (Assigned Allowance Unit).

On the other hand we find the transactions based on projects through what is called Joint Implementation-JI (Article 6 of the Kyoto Protocol): "Article 6: 1. For the purpose of meeting its commitments under Article 3, any Party included in Annex I may transfer to, or acquire from, any other such Party emission reduction units resulting from projects aimed at reducing anthropogenic emissions by sources or enhancing anthropogenic removals by sinks of greenhouse gases in any sector of the economy..." [38] that allows industrialized countries to acquire credits, called Emission Reduction Units or ERUs, whereas they fund emissions reduction projects in the so-called "countries in transition economy" that are listed in Appendix B of the Kyoto Protocol. The second choice for project-based transactions is contained in Article 12 of the Kyoto Protocol. These are called Clean Development Mechanism, or CDM. Those mechanisms offer the ability for industrialized countries to finance emissions reduction projects in non-Annex 1 countries, i.e., in developing countries or non-industrialised countries. In doing so, they receive credits called Certified Emission Reductions or CERs, which can be used to meet their emission objectives. However the JI is considered as independent from the compliance obligations that need to be met by the Parties of the Protocol Annex 1. The concept refers to rules of the market by which the industrialised countries have to financially assist developing economies countries and in return receive rights emission. In order to fall under the classification of what a Project is for the purpose of trading will need to be aimed at reducing $\mathrm{CO}_{2}$ emissions, $\mathrm{CO}_{2}$ capture and storage projects, or projects aimed to support a sustainable development that generally speaking plays a key role in the reduction of greenhouse gases.

Since most of the countries or parts included in Annex 1 are countries in the European Union, it is within the European Union where the largest regulated market exchange in the world is constituted. It is also helpful to understand the existence of a voluntary regime market, i.e., a market that is not regulated under the Kyoto Protocol and one that arise from the initiative of a company or private entity that actively contributes to moderating the global warming phenomenon. This voluntary market can further be subdivided into two.

As clearly explained by the document prepared by the department for Agriculture and Environment of the Regional Government of Aragon (Spain) puts: "In a broad sense, the voluntary carbon market can also be divided into two sublevels: The CCX or The Chicago Climate Exchange, which is a voluntary but legally binding market. And the secondary market ('over-the-counter' or OTC market), not legally binding. Also called domestic offsets. The CCX Chicago Climate Exchange or The Exchange is defined as the only record of greenhouse gas-based integrated and multi sectorial legally binding greenhouse standards for North America. It is a con- 
sidered a voluntary market as its membership is voluntary, but the operation is under a program of cape and trade, and the vast majority of loans are based on allowances ...” [39]. As it can be seen, other relevant international actors such as the US is also harbouring a trading market for carbon allowances, but it is not regulated or mandatory. This will become a very relevant issue in the dispute that arises because of the European Commission Community rules on aviation.

Thus, we see that there was already a regulated market which basically affected the member countries of the EU. It is within this market that the regulatory authorities will direct the aviation industries $\mathrm{CO}_{2}$ and other greenhouse gases levels. Overtime the European Commission concern have grown over the influence of the sector in relation to the global warming problem and given that there was already a regulated market, the European Commission has decided to tackle the problem with a new Directive that would change the general framework originally established in 2003 via the Directive 2003/87/EC.

Of all the regulatory controls at their disposal, the fact that the European Commission decided to regulate the situation by the means of a Directive, shows the desire of the Commission to allow a period of adaptation to stakeholders, mainly the airline companies, so they could adjust their financial position for these purposes. The Directive allows a period of time to incorporate its guidelines in the domestic law of each EU Member State. As the European Commission itself says: "EU directives lay down certain end results that must be achieved in every Member State. National authorities have to adapt their laws to meet these goals, but are free to decide how to do so. Directives may concern one or more Member States, or all of them. Each directive specifies the date by which the national laws must be adapted-giving national authorities the room for manoeuvre within the deadlines necessary to take account of differing national situations." [40]. This a reasonable period of harmonization envisaged within Member States that affect those airlines that conduct their business within EU airports. This way the Directive 2008/101/EC of 19 November 2008 came into being, was therefore amended by including the commercial aviation sector framework Directive 2003/87/EC.

This Directive has been complemented and rectified by subsequent regulation: The Commission Decision 2009/450/EC of 8 June 2009 on the detailed interpretation of the aviation activities listed in Annex I to Directive 2003/87/EC and, more recently, by Decision No 377/2013/EU of the European parliament and right of the Council of 24 April 2013 on a temporary directive 2003/87/EC with regard to the suspension of enforcement measures. It deviates from those taken against aircraft operators that during the year 2012 have not reported the emissions incurred from flights departing or arriving to EU airports. It is understood that during this period, the European trading scheme is voluntary and not mandatory for these flights. Moreover it complements and explains the list of aviation activities described in Annex I of the Directive. The Commission has provided detailed practical information in its "Guidance Document (July 2012) The Monitoring and Reporting Regulation-General guidance for Aircraft Operators.” [41].

And more recently we find the Regulation (EU) No 421/2014 of the European Parliament and of the Council of 16 April 2014, which is also amending the Directive 2003/87/EC. This particular regulation specifies technical matters of no lesser importance. Specifically, the regulation for air carriers is modified to fit the $38^{\text {th }}$ Assembly of the Association of International Civil Aviation Organization (ICAO. A-38) which was attended by 191 member states and other international organizations also invited in September 24-October 4 2013 [42]. Changes are made to the Directive 2003/87/EC (Article 28a and Annex K) meaning that flights performed by not commercial carriers that emit less than a thousand tons of $\mathrm{CO}_{2}$ per year will be excluded from the application of this Directive from 1 January 2013 until 31 December 2020.

The ultimate goal of this Assembly was the move towards a global standard through which an international agreement would enable the application and implementation of a single global market for emissions from international aviation around the World.

Another very interesting derivation of the Assembly 38 is the Decision 377/2013/EU of the European Parliament and of the Council of 24 April 2013 a temporary Directive 2003/87/EC which is the suspension of enforcement measures for those aircraft operators that do not report relevant emissions concerning flights from and to third countries to the EU or that haven't delivered their emission rights information for the year 2012 under the European system of trade allowances. It is also stated that the involvement of the companies in this proposal is voluntary: "Whereas 6: In order to facilitate this progress and provide momentum, it is desirable to defer the enforcement of requirements arising prior to the 38th session of the ICAO Assembly and relating to flights to and from aerodromes in countries outside the Union that are not members of the European Free Trade Association (EFTA), dependencies and territories of States in the European Economic Area (EEA) or countries having 
signed a Treaty of Accession with the Union. Action should therefore not be taken against aircraft operators in respect of the requirements resulting from Directive 2003/87/EC of the European Parliament and of the Council for the reporting of verified emissions for the calendar years 2010, 2011 and 2012 and for the corresponding surrender of allowances for 2012 from flights to and from such aerodromes. Aircraft operators who wish to continue to comply with those requirements should be able to do so" [43]. This policy, called "stop the clock" was the response of the European Commission to the international controversy over the inclusion of international air carriers to the standard of emissions, thus buying time until a global solution could be agreed.

However the main cornerstone of $\mathrm{CO}_{2}$ emissions control remains the Directive 2008/101/EC of 19 November 2008, amending the Directive 2003/87/EC. The consequences have basically incurred delays or exceptions to it. The transposition into domestic legal systems of each Member State of such Directive had to be completed before February 10, 2010 (Article 2): "Article 2: Transposition: 1. Member States shall bring into force the laws, regulations and administrative provisions necessary to comply with this Directive before 2 February 2010. They shall forthwith inform the Commission thereof. When Member States adopt those measures, they shall contain a reference to this Directive or shall be accompanied by such reference on the occasion of their official publication. The methods of making such reference shall be laid down by Member States. 2. Member States shall communicate to the Commission the text of the main provisions of national law which they adopt in the field covered by this Directive. The Commission shall inform the Member States thereof' [44]. It introduces new measures which are articulated within the general body of the Directive 2003/87/EC. Specifically, the new text is inserted in Articles 1, 2, 3, 6, 11, 13, 15, 18, 25 and 30 of Directive 2003/87/EC, Articles 14 and 16 are amended and shall be replaced 15 of the Directive 2008/101/EC of 19 November 2008.

Another item of particular interest is in the temporal scope of the Directive. The proposed regulation covers the period 2012-2020. The technique used by the EU to achieve this reduction is based on calculating the basis of $\mathrm{CO}_{2}$ emissions averages 2004-2006 and calculate the percentages from which the various airlines are forced to buy permits to emit $\mathrm{CO}_{2}$.

In general terms the main points of the Directive would be as follows:

- All flights departing and arriving at airports in the EU have to comply with the Directive and they are responsible for controlling their $\mathrm{CO}_{2}$ emissions (territorial criteria). The Directive, when interpreted by logical inference, states that these flights are to be of commercial nature, governed by the definition and exceptions listed in Annex I of the Directive. Exceptions to the Directive are clearly interpreted retrospectively by the Commission Decision of 8 June 2009.

- The limits on $\mathrm{CO}_{2}$ emissions would be $97 \%$ of average 2004-2006 levels by 2012 and 95\% in the period 2013-2020 (Article 3, Chapter II, c)

- Baseline values were calculated as the average of emissions from the aviation sector in the years 2004, 2005 and 2006. These values were quantified in March 2011 by the European Commission's White Paper on Transport in 221 million tons of $\mathrm{CO}_{2}$ [45].

- Aircraft operating companies need to deliver their emissions information in ton/kilometre criteria date of 2010 in order to obtain their free emissions allowances. If they exceed these free allowances, they will have to compensate the excess by going to the emission rights market. On the other hand if they do not meet their quota, they may negotiate the excess.

- A formula is used to calculate the quote for each aircraft operating company. The base value is multiplied by the ton $/ \mathrm{km}$ values for each operator date 2010. Each operator then receives $85 \%$ (2012) or $83 \%$ (years 2013-2020) in free emissions allowances.

- A reserve of $3 \%$ of the emission limit is established for special cases: Operators who start their business after 2010 and those showing an increase of over 18\% year over year (YOY) using as reference date the first and the second activity year.

- Every Aircraft operating companies will be controlled by an EU Member State. The assignment list of operator-State is published annually (for 2009, Regulation (EC) No. 748/2009 of $5^{\text {th }}$ August 2009. For 2010, Regulation (EC) No. 82/2010 of the Commission $28^{\text {th }}$ January 2010. For 2011, Regulation (EC) No. 115/2011 of the Commission on February 2nd 2011 . For 2012, Regulation (EC) No. 100/2012 of the Commission on February $3^{\text {rd }}$ 2012. For 2013 two Regulations. One general Regulation (EC) No. 109/2013 of the Commission on January $29^{\text {th }}$, 2013. And another posterior additional regulation considering Croatia's incorporation to the EU as its $28^{\text {th }}$ Member State: Regulation (EC) 05/08/2013 number of the Commission of $27^{\text {th }}$ August 2013. For 2014, the list operator-state control is outlined in Regulation (EC) No. 100/2014 of the 
Commission on February 5 $5^{\text {th }}, 2014$.

- The remaining $15 \%$ of emissions rights (2012) or $17 \%$ (2013-2020) is given by the auctioning method. (Article 3, d, Chapter II, of the Directive 2008/101 /EC of 19 November 2008): “Article 3d: Method of allocation of allowances for aviation through auctioning: 1 . In the period referred to in Article 3c(1), $15 \%$ of allowances shall be auctioned 2. From 1 January 2013, 15\% of allowances shall be auctioned. This percentage may be increased as part of the general review of this Directive" [46]. When an operator needs more allowances it will face two options. It can reduce its emissions, or it can buy more allowance elsewhere, either from the auction regulator, from other airlines, facilities or intermediaries or it can buy Clean Development Mechanisms - CDM or Joint Implementation-JI credits.

- Verification of the emissions: it is up to each controlling Member State to establish the verification method or agencies, though companies can appoint a verifier accredited by a national accreditation body in another EU Member State. The European Cooperation for Accreditation website provides a list [47]. For instance, the UK has established the following guidelines: "Verified emissions reports. Before you submit your emissions report to your regulator, you must first submit it to an accredited (or certified) verifier for verification in ETSWAP. Excluded installations can choose to self-verify or use an accredited (or certified) verifier. Aircraft operators who emit less than 25,000 tonnes of $\mathrm{CO}_{2}$ per year (based on the full scope of the EU ETS) can choose to determine their emissions using Eurocontrol's small emitters tool and data from its ETS Support Facility, or use an accredited (or certified) verifier. Your verifier cannot complete your report: their role is to provide an independent check of your report." [48]. Spain directly provides the companies with the proper templates for self-verification [49].

- The Directive 2008/101/EC of 19 November 2008 was transposed into Spanish domestic law through the second provision of Law 5/2009 of $29^{\text {th }}$ June 2009 and by Law 13/2010 of $5^{\text {th }}$ July 2010. The latter has amended the Law $1 / 2005$, of March $9^{\text {th }} 2005$, regulating the greenhouse gas trading emission rights regime in Spain.

Ultimately, it is up to each controlling Member State to grant the allowances to the aircraft operators that has been assigned within its jurisdiction. The allowance list is allocated annually for each single aircraft operating company. In the case of the Kingdom of Spain, the Spanish Ministry of Environment, through the Spanish Office for Climate Change, is entirely responsible of the published list [50].

\section{Regulation Impact}

The main effects on the commercial aircraft companies of this regulation can be summarised in a) the extra costs that the companies inclusion into the European $\mathrm{CO}_{2}$ trade emission market may mean; b) if it really is an effective system to control $\mathrm{CO}_{2}$ emissions and finally; c) the penalties that the companies may incur if they fail to comply with the strict guidelines of the Directive.

It can be argued if the costs of such regulations have a clear negative cost impact on companies. Seemingly aircraft operators will face additional operating costs. As seen in the flow of the figure developed by J. Faber, L. Brinke in their "The Inclusion of Aviation in the EU ETS to: Economic and Environmental Consequences" below, the impact of including the costs for the acquisition of $\mathrm{CO}_{2}$ emission rights flows through different channels. You can have a double effect: improving efficiency or an increase in the price of tickets, which may affect the demand for them. However, as they state in their ICTDS report: "In the aviation industry, the fuel efficiency is a common requirement and that fuel costs represent one of the biggest costs in running an airline. The measures include the installation of wing tip, weight reduction, the fleet renewal and optimization of flight routes, among others." [51].

Other studies claim that fuel prices are highly volatile therefore; the extra costs can be compensated without burdening the passenger's costs. As a matter of fact, in recent months, oil prices have been in constant decline.

Prices have fallen worldwide, with a difference on October $24^{\text {th }} 2014$ on the prices of $-16.2 \%$ from same date last year and at European level, with a difference of 16.7\%, if we are assuming Europe means a $28 \%$ of the total consumption of aircraft fuel [53].

It could therefore be argued that the price increase is due to the $\mathrm{CO}_{2}$ emissions factor and thus absorbed by the reduction in fuel price. The European Commission concludes that the cost impact on airlines is only marginal and unlikely to be a motivating factor for airlines and passengers to choose other non-EU airports. The Commission finds that the number of allowances that are needed by the aviation industry for a particular route is ad- 
justed in proportion compared to the general emissions trading framework in the European Union. The average cost of emission rights is integrated as another factor on the overall price of the aircraft fuel [54]. The Commission also finds that the extra cost impact in the price of economy class tickets as being between $0.1 \%$ and $1.1 \%$ of the total ticket cost [55].

Another factor to be taken into consideration is the impact of these cap and control policies in terms of reining the GHG emissions themselves. This is the ultimate aim of any environmental policy. Those policies are not created as a way of getting extraordinary economic resources by the regulator; this is only a means to an end: curving the GHG emissions and its global warming consequences. A study by Faber J., Brinke L. from the ICTDS explains that at current prices, it is cheaper for aircraft operators to assume the additional cost of obtaining emission allowances from other sectors that have to implement measures to reduce their own emissions. The same authors conclude that "the impact on net emissions covered by the EU ETS could be large, because aviation emissions are projected to grow strongly. Therefore, the airlines will have to offset an increasing share of their emissions through buying allowances from other sectors in the EU ETS or Kyoto project credits" [56]. It seems that thus ignoring the issue would not help into the general curving of the overall GHG emissions, given the increased importance of the aviation industry emissions within the general framework.

Finally, as far as potential penalties for the companies are concerned the "stop the clock" policy means that so far only penalties for lack of informing in due time have been disclosed. There is some information in local State Member official sites about the exposure to penalties companies may face. In the UK the British Environment Agency stated in December 2013 that "If you fail to comply with a condition of your approved emissions plan (or other requirements in the Regulations), you may be liable to a civil penalty. Approved emissions plan holders can also receive a penalty of $€ 100$ per tonne of $\mathrm{CO}_{2}$ if they fail to surrender sufficient allowances by 30 April each year to cover emissions during the previous year." [57]. The same document refers for details regarding penalties to an item that almost a year later has been archived: "Application of Civil Penalties. Phase III of EU ETS has introduced a civil penalty enforcement regime. This means that if you do not meet legal requirements you may be liable for a civil penalty as specified in Part 7 of the Greenhouse Gas Emissions Trading System Regulations 2012. The penalty for failure to surrender sufficient allowances to cover your annual emissions remains at 100 Euros per tonne of CO2.Our overall approach to enforcement is published in our Enforcement and Sanctions Guidance. Enforcement and Sanctions Guidance: We are currently amending this guidance to provide more comprehensive information about how we will manage enforcement for EU ETS. Before finalising our policy, we will consult on our approach. We hope to launch the consultation before Christmas or if this is not possible in early January. The consultation will be open for 10 weeks and we will notify you when it goes live. You will be able to read and respond to the consultation via our Consultation Portal” [58] as it can be inferred, no real penalties policy to be informed of is available at the current moment.

\section{International Reactions}

\subsection{EU Overview}

The EU seeking a way to reduce the commercial aviation industry GHG emissions has produced a regulation affecting companies landing or taking off from any EU airport. However the regulation is affecting not only European companies and furthermore in international flights most of the GHG emissions are produced out of the European airspace. For example, a Madrid-Tokyo flight operated by a non-European carrier such as JAL, must cover the emission rights of all the length of the flight emissions, i.e. not only the emissions produced in the EU airspace but also those occurring in third countries, and the emissions produced while flying offshore and while flying in Japanese airspace. Thus a controversy is created. The key issue is to identify the EU boundaries as far as trade and air transport is concerned. The debate has produced, as it is rather logical in the multipolar world of the $21^{\text {st }}$ century, a clash with other major trading blocs. Notably the US, China and India have expressed their dissatisfaction with the unilateral European system.

Historically, as it is already mentioned, the Kyoto Protocol included in its discussions the emissions from the commercial aviation industry and the very Protocol commended the ICAO in the Article 2.2 to develop a policy aiming to rein them. It can also be inferred that the terms used in the Protocol were rather vague, basically postponing the issue for further meetings in the specialised UN Agencies. Since then, the various ICAO Assemblies have not finalised any specific measure. This has triggered the unilateral EU response. The fact that a very relevant international party is taking unilateral decisions does not mean the article 2.2 mandate is deemed invalid or 
annulled. And this lack of international consensus and mismatch in the identification of the appropriate legal framework for the controversy is the basis of many of the complaints from other relevant parties on the international scene.

Adding to the controversy there are other international obligations that the EU has assumed and that we find conflict with the unilateral regulation of the matter. It is convenient to recall the existence of free airspace policy which culminated in the Open Skies Agreement made between the European Union and the United States. The Air Transport Agreement was signed on $25^{\text {th }}$ and $30^{\text {th }}$ April 2007 and it was provisionally applicable as of March $30^{\text {th }}, 2008$ to all Member States. On June 24 ${ }^{\text {th }}, 2010$ the Agreement is amended via a Protocol and Norway and Iceland became part of it from $21^{\text {st }}$ June 2011. The Agreement "represents an important step towards the normalisation of the international aviation industry. The ultimate objective of the European Union is to create a transatlantic Open Aviation Area: a single air transport market between the EU and the US with free flows of investment and no restrictions on air services, including access to the domestic markets of both parties.” [59]. This Agreement will be widely remembered in the later controversy generated by the Directive.

The United States was the party that first reacted to the Directive. The Air Transport Association of America (ATAA), along with the most important airlines in the country, used the UK as a legal platform to contest the Directive. The UK was the first EU state to incorporate the Directive into national law in 2009. In a fellow common law legal order close to the US own the US found the most convenient legal battleground for litigating the Directive [60]. However, the case was referred by the High Court of England and Wales to the High European Courts, as only the European Court of Justice (ECJ) has the power to declare invalid regulation emanating from the European Union. The case raised controversy beyond the courtyards, and on October $6^{\text {th }}, 2011$ the ECJ Advocate General Dr. Julianne Kokott states that the EU regulation was compatible with the relevant international agreements signed by the EU and raised by the case parties [61].

\subsection{European Court of Justice Decisions}

As already noted, the plaintiffs were on one side three American airlines, specifically, American Airlines Inc., Continental Airlines Inc. and United Airlines Inc., in the case identified as "Companies” by the American Association for the Air Transport (for the “ATAA”). They raised the issue by suing the Secretary of State for Energy and Climate Change in the UK before the High Court of England and Wales, who referred the case in May 2010 the European Court of Justice to be whoever solves this as a preliminary question. It is worth recalling that for the European Court of Justice, located in Luxembourg, is in charge of overseeing the legality of acts from the institutions of the European Union, to ensure compliance by Member States, and to interpret the law of the Union European when requested by national courts of Member States and it is the Supreme Court to which all Member States have to submit: “... 33. The Court of Justice of the European Union shall, in accordance with the Treaties: (b) give preliminary rulings, at the request of courts or tribunals of the Member States, on the interpretation of Union law or the validity of acts adopted by the institutions." [62].

It is a complex case, in which are also present as parties the ICAO itself, the National Council of Canadian airlines (NACC), the Federation for the Environment in Aviation, the European Federation for Transport and Environment, the Environmental Defence Fund, and the private organisation Earthjustice.

The plaintiffs argued that the inclusion of commercial aviation companies in the European emissions trading allowances program breached international standards and agreements. They focussed the demand in the violation of the Kyoto Protocol, the 2007 Open Skies Agreement between US and EU and the Chicago Convention. They also understand that the Directive exceeds the jurisdiction of the EU and that in fact the inclusion of the aviation companies in the emissions scheme was nothing but a tariff or hidden tax. On the other hand the ECJ also considered the defence of the United Kingdom, where it was claimed that the contested Directive should be interpreted as a measure of international incentive leading to encourage other States to take similar measures, and that it is compatible with the existing international agreements.

On October 6, 2011 when one of the eight ECJ Attorneys General, Dr. Juliane Kokott validated the Directive: Article 252: “(ex Article 222 TEC) The Court of Justice shall be assisted by eight Advocates-General. Should the Court of Justice so request, the Council, acting unanimously, may increase the number of Advocates-General. It shall be the duty of the Advocate-General, acting with complete impartiality and independence, to make, in open court, reasoned submissions on cases which, in accordance with the Statute of the Court of Justice of the European Union, require his involvement” [63]. Although the Advocate General's Opinion is not binding by itself it is an unavoidable part of the process of a preliminary question to the ECJ and it is usually taken very much into 
account by the Court [64]. In the opinion of Advocate General Dr. Kokott, no elements that could invalidate Directive 2003/87/EC as amended by Directive 2008/101/EC were found.

Advocate General Dr. Kokott finds the EU is not a State Party to the Chicago Convention, as this was signed by the several States comprising the EU, but not by the EU as an entity. She also reminds that the then 27 Member States belong to the ICAO, but the EU only has observer status with this Agency, so no there is no need to contemplate the validity of Directive questioned in light of the aforementioned Convention. The fact that the EU has not signed the Convention encouraged in her own words that it cannot be liable neither are bound by it: "The general principle-recognised also under international law-of the relative effect of treaties applies, according to which treaties do not confer rights or impose obligations on third States ('pacta tertiis nec nocent nec prosunt')." [65].

As to whether the Theory of Succession or Functional Surrogacy is to be applied. It is worth reminding the Judgement in Case C-301/08 in which the ECJ maintained that the EU was to be considered as subrogated in the international obligations undersigned by the European Economic Community at the GATT agreement in the case of the International Fruit Company. The Attorney General finds that this theory is not automatically applicable to the current case, since the powers related to the aviation sector have not been fully transferred to the EU by the Member States, and also and in fact, in several international agreements concerning this industry both the EU and Member States individually, are found as signatories. Similarly, the U.E. is not as a member of ICAO instead of the 28 Member States [66].

As to the Kyoto Protocol issue, the Attorney General admits that it was actually ratified by both the $27 \mathrm{EU}$ members in 2011 and the European Community, surrogated from the Lisbon Treaty by the European Union.

However, she finds legal rationale for the contested Directive that supports it. She cites Article 2.1.a.vii the Protocol which allows parties to take "Each Party included in Annex I, in achieving its quantified emission limitation and reduction commitments under Article 3, in order to promote sustainable development, shall:... (vi) Encouragement of appropriate reforms in relevant sectors aimed at promoting policies and measures which limit or reduce emissions of greenhouse gases not controlled by the Montreal Protocol" and she recalls that that Treaty makes explicit reference to aviation in Article 2.2 [67]. It is also stated that the Kyoto Protocol is a as a matter of fact a general framework treaty with no specific consequences for individuals, so it cannot be used by individual legal entities such as airlines for legal claims. The Attorney General asserts that “... All the commitments in the Kyoto Protocol have to be transposed into national law and, moreover, they are not sufficiently precise to be capable of having a direct beneficial or adverse effect on individuals" [68].

Although the Kyoto Protocol does not seem to be claimed by individual parties, the Attorney General herself is of the opinion that individuals can use the Open Skies Agreement in their legal rationale. In this case, it is admitted that the Treaty itself gives way to the concept of individual "All in all, therefore, I am of the view that the Open Skies Agreement can, by its nature and broad logic, affect the legal status of individuals. In legal proceedings brought by individuals, the Open Skies Agreement may therefore, in principle, be used as a benchmark against which the validity of EU acts can be reviewed" [69], Therefore she accepts that a claim under this Agreement, but she reduces its impact to its article 7, regarding the application of the rules: "1. The laws and regulations of a Party relating to the admission to or departure from its territory of aircraft engaged in international air navigation, or to the operation and navigation of such aircraft while within its territory, shall be applied to the aircraft utilised by the airlines of the other Party, and shall be complied with by such aircraft upon entering or departing from or while within the territory of the first Party. 2. While entering, within, or leaving the territory of one Party, the laws and regulations applicable within that territory relating to the admission to or departure from its territory of passengers, crew or cargo on aircraft (including regulations relating to entry, clearance, immigration, passports, customs and quarantine or, in the case of mail, postal regulations) shall be complied with by, or on behalf of, such passengers, crew or cargo of the other Party's airlines" [70] and the article 15.3., regarding the environment: "Article 15. Environment... 3. When environmental measures are established, the aviation environmental standards adopted by the International Civil Aviation Organisation in Annexes to the Convention shall be followed except where differences have been filed. The Parties shall apply any environmental measures affecting air services under this Agreement in accordance with Article 2 and 3 (4) of this Agreement" [71]. As the principle of territoriality is concerned, on this point, the Advocate General considers that "156. Contrary to the view taken by the claimants in the main proceedings and the associations supporting them, Directive 2008/101 does not, either in law or in fact, precludes third countries from bringing into effect or applying their own emissions trading schemes for aviation activities. 157. Admittedly, if sections of 
flights that take place over the high seas and within the territory of third countries are included there is a risk of 'double regulation', that is to say, a risk of one and the same route being taken into account twice under the emissions trading schemes of two States. This might be the case, in particular, if emissions trading scheme applicable at the place of departure of an international flight and the scheme applicable at its place of destination were both-like Directive 2008/101-to take account of the whole flight. 158. Nevertheless, however onerous it might be for the airlines concerned, such double regulation is not prohibited under the principles of customary international law at issue here. It is indeed accepted under customary international law, just as the widespread phenomenon of double taxation is accepted in the field of direct taxation." [72].

As usual, the decision in Case C-366/10, issued on December 21, 2011 follows the guidelines of the opinion of the Attorney General Conclusion in its final decision that "The review of Directive 2008/101 has not revealed element affecting its validity" [73].

Thus, there was no impediment from the European supreme courts for the contested Directive to spread its effects.

This Judgement prompted a quick response from the US in late 2011. The US Secretary of State Hillary Clinton and Secretary of Transportation Raymond $\mathrm{H}$. LaHood declared that "are strongly opposed by legal and political reasons" for the implementation of the Directive on Aviation US airlines and urged the EU to stop, suspend or delay the implementation of the Directive in its letter to the European Commission on December 16, 2011, while they “... urge the EU and its Member States within the respective competences to return to working with, rather than against, the international community in the appropriate multilateral forum- the ICAO-to address the important challenge of reducing aviation emissions". This letter also includes a further provisional list of nations opposing the UE measures [74].

Shortly before the letter, on October 24, 2011, the US House of Representatives approved a bill that would make it illegal for airlines of the United States to comply with the EU Directive. In a very diplomatic tone it displays little precise legal effects. It states that "There is no assurance that ETS revenues will be used for aviation environmental purposes by the European Union member states that will collect them." (Section 2, paragraph six) "The Secretary of Transportation shall prohibit an operator of a civil aircraft of the United States from participating in any emissions trading scheme unilaterally established by the European Union.” (Section 3) [75].

This bill is signed by President Obama and became Public Law on November 27, 2012 [76]. The regulatory framework is very nebulous as for real specific penalties for those who infringe it, but it provides a general framework within which to develop in detail this norm in the future as it is clearly designed as a legal tool for the US Government to negotiate the matter with the EU: "Section 4. Negotiations: The Secretary of Transportation, the Administrator of the Federal Aviation Administration, and other appropriate officials of the United States Government shall use their authority to conduct international negotiations and take other actions necessary to ensure that operators of civil aircraft of the United States are held harmless from any emissions trading scheme unilaterally established by the European Union" [77].

This regulation did not mean a specific legal framework with specific penalties for any US commercial airlines that decided to be included in the European scheme. The US has not involved the World Trade Organization in the controversy to date. But then, in early 2012, the Commission acknowledges how strong international opposition to the Directive will be.

Additionally, as the Congressional Research Service informs "the House approved in June 2012 an amendment to the Transportation, Housing, and Urban Development Appropriations bill (H. Amdt. 1356 to H.R. 5972) to prohibit FY2013 funds from being used to support implementation of the EU ETS on aviation activities" [78].

Also, China strongly opposed to the Directive. It stated that the inclusion of its airlines in the ETS of the EU violates the United Nations Framework Convention on Climate Change (UNFCCC) as it infringes the principle of Common But Differentiated Responsibility (CBDR). This principle states the idea that you should not expect the same level of effort in developed and in developing countries when it comes to reducing GHG emissions and that this inclusion equally violate the Convention on International Civil Aviation. The Chinese Air Transport Association (CATA) expressed their opinion about the matter: "CATA, which represents China's largest airlines, sent representatives to Brussels earlier this month to negotiate with the EU and make it clear that Chinese carriers won't accept their inclusion in the EU ETS, calling it illegal and a violation of the Chicago Convention and of "Common but Differentiated Responsibility" principles regarding $\mathrm{CO}_{2}$ emissions." [79]. Also, the ICAO released a statement opposing the EU Directive on Aviation in the parts that obliges third countries to buy allowances [80]. China also threatened to take the matter before the German Courts. According to their calcula- 
tions, the inclusion of Chinese airlines in the EU emissions scheme would mean a cost of 2.4 billion yuan in 2020, something unaffordable in a country that is not part of Appendix 1 of the Kyoto Protocol [81].

Chinese pressure is accentuated not only unilaterally. On the one hand China signed a joint statement with the Russian Federation on July 7, 2011 on the "inclusion of aviation activities in the system of emission trading market of the European Union" to condemn it, not excluding the possibility of bringing on pressure measures. China also hinted taking additional measures, such as tax offsets to Chinese airlines concerned or even turning down the purchase of aircrafts from European manufacturers, the Airbus 330 and 380 models, in favour of their Boeing competitors [82]. China made an effort not to be shown as isolated in this matter, on the contrary, it led efforts of an important local movement against the measures in Asia: "The International Air Transport Association, the Air Transport Association of America, and the Association of Asia Pacific Airlines actively responded to the invitation and sent representatives for the meeting. The delegates discussed the issues related to the incorporation of air transport industry into the EU ETS and the serious impact that will or may have on the global airline operation and its sustainable development...The delegates agreed that: Parties support the concept of Green Aviation with Low Carbon Flights. We hold it firmly that the EU ETS is a violation of relevant instruments of international law and detrimental to the sovereignty of other countries. This unilateral action will seriously undermine the sound and sustainable development of the global air transport industry. We are strongly opposed to such a plan. Parties call upon the governments to give attention and support to our position against the planned inclusion of airlines into the EU ETS, and work together with us to promote the sustainable advancement of the international aviation industry." [83].

India also protested this unilateral move by the EU. Indian Environment Minister Natarjan wrote a warning letter to the European Environment Commissioner Connie Hedegaard on December 28, 2011, which warned that "I strongly urge the EU to reconsider and reverse the decision to apply the scheme to non-EU airlines...India strongly feels that a unilateral measure as the one proposed to be taken by $E U$, stands not only in violation of the principles and provisions of the (international) convention but will also not augur well for the success of future climate change negotiations." [84].

\subsection{The Current Situation}

In this context of international controversy and with the first phase about to come, the European Commission decided somewhat surprisingly in November 2012 a temporarily suspension of the inclusion of international aviation in the European emissions market. This suspension was brief, a year. And it did not imply an exclusion of the program as once the period was finished the clock would start again, including the phase for the year 2012 and the phase for the years 2013-2020. Neither was it a general suspension for all flights as all flights within the European Economic Area would not be under the effects of "stop the clock". The purpose of the "stop the clock" decision was to give opportunity to the International Civil Aviation Organization ("ICAO") to try to negotiate a comprehensive agreement addressing emissions from international aviation in the meeting of the Assembly ICAO in September/October 2013, in Montreal, Canada.

There, on October 4 2013, ICAO concluded two weeks of negotiations in which it was agreed to develop a global system based on a market model of emission rights. This system is called MBM (Market Based Measures), and follows the lines that ICAO had already anticipated in 2011 [85].

The A38 also called for an agreement regarding these measures on the next Assembly (A39) in 2016 with the goal that the system could be implemented in 2020. That means that no the A38 did not arrive to any binding agreement and the decision was postponed tom the A39 in 2016. The text of the agreement of the 38 ICAO Assembly in Montreal explicitly explains this point of view "Recalling that Assembly Resolution A37-19 requested the Council, with the support of Member States, to undertake work to develop a framework for market-based measures (MBMs) in international aviation, including further elaboration of the guiding principles listed in the Annex to A37-19, for consideration by the 38th Session of the ICAO Assembly; Recognizing the importance of avoiding a multiplicity of approaches for the design and implementation of MBM framework and MBM schemes; Recalling that Assembly Resolution A37-19 requested the Council to explore the feasibility of a global MBM scheme to address emissions from international aviation;... 9. Agrees to review, at its 39th Session, the goal mentioned in paragraph 7 above in light of progress towards the goal, studies regarding the feasibility of achieving the goal, and relevant information from States;” [86].

The Assembly also rejected proposals to at least include flights within a particular airspace within a local sys- 
tem of emission rights market. This would give legal international cover to parts of the EU Directive and it was proposed by the ICAO Council itself. This concept of flights within a "sovereign airspace" is rejected in the vote of the Assembly. What the Assembly adopts with regard to regional markets right issue is resolved by stating that “... Resolves that States, when designing new and implementing existing MBMs for international aviation should: a) engage in constructive bilateral and/or multilateral consultations and negotiations with other States to reach an agreement, and b) grant exemptions for application of MBMs on routes to and from developing States whose share of international civil aviation activities is below the threshold of $1 \%$ of total revenue ton kilometres of international civil aviation activities, until the global scheme is implemented;” [87]. This implies that the EU should make a bilateral agreement between each Member States and third countries to include commercial aviation in their respective emission rights market. This was also the Chinese point of view in its objections to the 2008 Directive. On a bilateral agreements scheme and under the Annex 1 of the Kyoto Protocol, these measures could not in any case apply to developing States. All this is far removed from the spirit manifested by the Commission on how to tackle the GHG emissions problems problem to date.

The response of the Commission was published in October 2013. This response was expected to take the form of a Directive dealing with the concept of “sovereign space”. This would mean a de facto discard of the A38 resolutions since it rejected this concept. Finally, this initiative sees the light as a Regulation: Regulation (EU) No 421/2014 of the European Parliament and the Council. The Commission final approach to the issue is shown as moderate. This regulation basically “extends the 'Stop the Clock' Decision to calendar years 2013-2016. The regulation also excludes certain flights between 'outermost regions' of the EEA for calendar years 2013-2016. Further, in addition to the existing de minimis exception, there is an ETS exemption for non-commercial aircraft operators with a total of less than 1000 tonnes $\mathrm{CO}_{2}$ per year from calendar years 2013-2020. Compliance dates for reporting emissions and surrendering allowances for calendar year 2013 emissions were extended to March and April 2015 to coincide with existing deadlines for calendar year 2014. Importantly, the regulation did not extend the ETS to portions of flights that take place in European regional airspace for flights between EEA airports and non-EEA airports" [88]. As it is clear the will of the European Commission is to keep on implementing an inclusion of the aviation industry in the ETS. On a practical level they are aiming for a soft approach as the level of international controversy remains high. So at the time being the aviation industry needs only to regard the ETS for flights within the EU. The discussion in this alert identifies only a small sampling of what are likely to be a plethora of issues and challenges that may arise from the lack of international consensus on emissions regulations. Although these issues may not appear to have immediate significance, they nonetheless deserve the consideration of parties who ultimately may be impacted by a broader ETS implementation. This is clearly the position of the three largest EU economies, which are not enforcing any penalties. The specialised media on aviation has very much noticed that "France, UK and Germany will not enforce sanctions for noncompliance” [89].

\section{Considerations about Potential Impact on Tourism}

There are two main points to be regarded in the relationship between tourism, aviation and greenhouse gases emissions.

First is size of the tourism industry. Tourism is one of the big global industries: "The overall export income generated by inbound tourism, including passenger transport, exceeded US\$ 1.2 trillion in 2011, or US\$ 3.4 billion a day on average. Tourism exports account for as much as 30\% of the world's exports of commercial services and 6\% of overall exports of goods and services. Globally, as an export category, tourism ranks fourth after fuels, chemicals and food" [90]. The scope of the tourism industry seems also extremely remarkable "by 2024, tourism could support some 347 million jobs and \$11 trillion in GDP.” [91]. The tourism industry means a very sizable present and future reality.

Since aviation started its commercial activities tourism and commercial aviation have been a symbiotic relationship. Tourism means connectivity and a big part of this connectivity comes from the aviation industry. This change in the size of the tourism sector has a double effect. In one hand the tourism industry is a contributor to the global warming reality. On the other hand it is affected by it. Many of the main touristic areas in the world will suffer from the climate change. This means the UN Agency in charge of the Tourism has the climate change as one of its paramount interests. Most specially in regards to the aviation industry, trying to find a balance between the two sides of the coin. Regarding the costs for the aviation industry but bearing in mind the need to add 
to curving the emissions: "At the global level, UNWTO is working with ICAO and with industry bodies—notably WTTC and IATA - to increase the coordination between air transport and tourism. The approach is to position travel and tourism collectively as a strategic industry, with air transport as an interconnected core, with a single voice on such issues as liberalization, security and facilitation, climate change, economic impact and tax." [92].

Second is its growth. As explained in previous chapters, the remarkable growth in the touristic segment choosing aviation as means of transport has been the motivation of the European approach to curve the GHGs coming from the aviation industry. The number of tourists arriving to their destinations by air will continue to grow. This is forecasted by the UNWTO:

However, the climate change is a reality that particularly worries the tourism industry. The UN states such a worry through the Madrid based UN Agency World Tourism Organisation: "For tourism, climate change is not a remote event, but a phenomenon that already affects the sector and certain destinations in particular, imountain regions and coastal destinations among jothers. At the same time, the tourism sector is contributing to greenhouse gas emissions ¡(GHG), especially through the transport of tourists.” [94]. Thus the dichotomy of assuming of assuming the cost of reining in GHG emissions or suffering the consequences.

On a practical level the main worry for the aviation industry is costs. More travelling by air would mean more business. This sizeable growth will mean more allowances to be bought. How will this impact on the costs? The impact of these costs depends on several factors: it will depend on their ability to manage fuel costs, operational efficiencies and above all, to what extent they are able to pass on such charges to the end user: the traveller. In this sense one must create the necessary dynamic market conditions for competition in a free market to thrive effectively. Forced to offset these additional costs, each operator will have to make executive decisions according to their own political situation; their balance sheets, their medium and long term strategic growth plans, the economic market cycles, or any other factor deemed necessary must be carefully taken into account.

Some research studies have worked out the cost impact of these measures on the prices of airline tickets and on the consumer demand of those tickets. Estimates range from a rise of one euro to six euros and sixty six cents average in short-haul flight tickets. For medium-haul flights tickets it has been calculated an increase of between one euro and eighty-nine cents euros and nine euros. For long-haul airline an increase between eight to forty euros has been pondered [95].

For the time being the industry is enjoying cheap fuel and a non-decisive policy regarding the acquisition of allowances. It is unclear how will it react if conditions change.

\section{Conclusions}

The commercial aviation industry links with the concept of globalisation. A globalised world is a connected world. And the commercial aviation industry allows us to travel vast distances. For business of for leisure, the relevance of the commercial aviation industry will do nothing but expand. A global sector requires an international forum of understanding. The importance of the aviation industry meant that creation of an international agency dates as early as 1944 . The ICAO has been since been the focal meeting point for a more complex industry. Many legislative bodies now play a role on it. Many bodies mean many interests. It is therefore complicated to deliver practical solutions and commitments in such a forum even when the matter is climate change. So far, any solution at the IATA forum has been delayed until 2016 at the earliest.

But a growing industry means an escalating problem. Prospects of emissions from the commercial aviation industry meant that growth was strong. However the world faces a more and more significant sector of the economy whose GHGs emissions were not regulated under the Kyoto Protocol or any other international agreement. The airlines did not have to offset an increasing share of their emissions through buying allowances from other sectors. Also, the EU already had an ETS program designed as a way for the EU to comply with its obligation under the Kyoto Protocol and its own strict objectives for skewing GHGs emissions.

It was only logical for the EU Commission to feel the impact of these factors, and thus take a unilateral decision to immerse this unregulated sector within the general framework. However globalisation means there are also other significant States in the world that felt the impacts of these measures on their national interests. In a civilised world, these kinds of controversies eventually find solutions in the judiciary. However, the ECJ found within the EU international such obligations are aimed towards the commercial aviation ETS Directive.

This led to a backlash of the some of the main international actors, US, China and India as they were not satisfied with the EU regulations. Especially once it became endorsed by the ECJ Judgement. The situation is cur- 
rently on hold as the European Union is aware it is not alone in such global matters and would unlikely wish to escalate any form of commercial war. It is currently biding its time for an international solution within the ICAO Assemblies. As the rest of the world observes a leading economic region taking decisions and awareness on climate change issues increases, pressure for the ICAO A39 of 2016 also grows. So far, the European ETS for the aviation industry only applies for local inner EU flights.

Tourism is also linked to the concept of connectivity. There has been an interdependent connection between commercial aviation and tourism since the first commercial flight took off. This has never ceased to be: "Aviation plays a central role in supporting tourism. Over 52\% of international tourists now travel by air” [96]. Commercial aviation also is growing in significance to take tourists to different parts of the world. If transport prices rise for travellers, then the whole industry which is the fourth largest within a global industry would suffer. So far declining fuel prices and the hold on policy means the situation is there but it has not yet been reflected in the industry costs.

In a sense the current controversy is a further chapter of the old question: who should carry the burden of fighting climate change? Ultimately the principle of common but differentiated responsibility remains at the core of the debate. "The principle of 'common but differentiated responsibility' evolved from the notion of the 'common heritage of mankind' and is a manifestation of general principles of equity in international law. The principle recognises historical differences in the contributions of developed and developing States to global environmental problems, and differences in their respective economic and technical capacity to tackle these problems." [97]. Which countries should carry that burden? If as stated the aviation industry shows developed State GHG emissions level and is able to lobby in front of strong relevant international parties as if it were a relevant State itself, shouldn't it be considered as liable in the common effort to rein in carbon emissions? The logic behind this concept would make sense of the wealthy aviation industry contributing to the developing countries efforts via the Emission Reduction Units or ERUs or the Clean Development Mechanism, or CDM programs. This sounds reasonable and ethical and it is one of the methods proposed by the European Union.

The European Union often sees itself as the only party really taking committed measures to curve GHG emissions as to avoid the limit warming of 2C above pre-industrial levels that would specially protect poor countries from climate change effects. Also, the EU leads the tourism attraction ranks. In one hand, the EU is setting itself with a roadmap towards the most ambitious GHG reduction plan in the world [98]. "Member States have realized the importance of low-carbon economies to fulfil their responsibilities in providing European citizens with sustainable economic growth, secure jobs, and a high standard of living...in order to reduce emissions by $80 \%-90 \%$ by 2050. This can be achieved notably by revise the Emissions Trading System, a central tool to the reduction of greenhouse gas emissions (GHG)" [99]. It also shows good numbers in that effort on the road to midpoint 2020. The European Commission feels the European approach is working [100]. On the other hand, the EU holds some of the leading countries in terms of tourism. In 2013 France was the most visited country in the world, Spain was the third most visited country after the USA and Italy was the fifth [101]. The EU is a magnet for commercial aviation, especially for tourism. It also hosts some of the most relevant airlines companies in the world [102]. And yet the European Commission estimated fair and pondered to burden the industry with extra costs in order to mitigate the global warming effect.

The developed world countries have promised billions to fight against the effects of climate change in developing countries. Many developing countries depend on the tourism industry. Where will this money coming from? Will the same parties that take profit on the tourism industry add to the efforts? The EU, the United States and even China have already pledged for cutting greenhouse gas emissions. Only time will tell if these efforts will be joined by State-size industries like commercial aviation before the tourism goose that lays the golden egg is killed by climate change.

\section{References}

[1] For an Introduction to Global \& Comparative Law \& Politics, We Suggest Sánchez-Bayón, A. (2014): “Global System in a Changing Social Reality: How to Rethink and to Study It” (p. 196-209), en Beijing Law Review ( ${ }^{\circ}$ 5). (2013a) Renovación de la Filosofía Social Iberoamericana, Valencia: Tirant. (2013b): "Enseñanzas del Prof. Navarro-Valls para comprender el “aggiornamento” del Ordenamiento global” (p. 1719-53), Martínez, et al.: Religión, Matrimonio y Derecho ante el siglo XXI (2 Vols.), Madrid: Iustel. (2013c): Teoría y praxis de los derechos humanos. Una guía para su exigibilidad, Madrid: Difusión Jurídica. (2012a): Filosofía Político-Jurídica Glocal, Saarbrücken: EAE. (2012b): Humanismo Iberoamericano, Guatemala: Cara Parens. (2012c): El efecto de la crisis y el futuro de la sociedad del 
bienestar, Madrid: Delta/ASEPELT. (2012d): “Repensar la normatividad” (pp. 181-217), ICADE (n85). (2012e): “Normatividad Global” (pp. 81-119), en Anales de la Facultad de Derecho-Univ. Laguna (n²8). (2011a): Sistema de Derecho Comparado y Global, Valencia: Tirant. (2011b): Introducción al Derecho Comparado y Global, Madrid: Delta. (2010a): “Au revoir, loi de l'État: el fin del derecho estatal” (pp. 143-162), Bajo Palabra (n ${ }^{\circ}$ 5). (2010b): “Conocer y gestionar las esferas sociales en la globalización” (pp. 103-146), ICADE (n ${ }^{\circ}$ 81). (2009): Estudios de cultura político-jurídica, Madrid: Delta. (2008-13): La Modernidad sin prejuicios (3 vols.), Madrid: Delta. (2005): “<<Crimen y castigo $>>$, ¿literatura o realidad jurídica? Retos del camino hacia la democracia y la paz” (pp. 61-68), Rev. CC. Jurídicas-Univ. Costa Rica (n ${ }^{\circ}$ 108). Sánchez-Bayón, A., Sánchez, S. (2014) "Glocal Politics and Law” (Chapter 2 p. 25-53), Manzanero, D., et al. (Edits.): Philosophical Changes of Plurality in a Global World, Cambridge: Cambridge Scholars Publishing.

[2] UNFCC (1997) Kyoto Protocol. Article 2.2.

[3] Assembly Resolution ICAO A33-, October 5 2001, Appendix I.

[4] Assembly Resolution ICAO A33-7, October 5 2001, Appendix I.c.2.

[5] Assembly Resolution ICAO A36-22, September 28 2007, Appendix J, 1, b.

[6] Rock, N., Zaman, P., Gordon, A. and Gilani, S. (2014) Aviation Emissions: The ICAO Outcome and Its Impact on the EU Aviation Emissions Trading Scheme.

http://www.reedsmith.com/Aviation-Emissions-The-ICAO-outcome-and-its-impact-on-the-EU-aviation-emissions-trad ing-scheme-01-07-2014/

[7] ICAO (2008) Guidance on the Use of Emissions Trading for Aviation. 21-22.

http://ec.europa.eu/clima/policies/transport/aviation/docs/icao_guidance_2008_en.pdf

[8] ICAO (2008) Guidance on the Use of Emissions Trading for Aviation. 26. http://ec.europa.eu/clima/policies/transport/aviation/docs/icao_guidance_2008_en.pdf

[9] Wit, R., Boon, B.H., van Velzen, A., Cames, M., Deuber, O., et al. (2005) Giving Wings to Emission Trading. Inclusion of Aviation under the European Emission Trading System (ETS): Design and Impact. Report for the European Commission, DG Environment No. ENV.C.2/ETU/2004/0074r. 9.

[10] O’Leary, A. (2013) EU Faces Dilemma as Aviation Climate Deal Stays Grounded. http://www.rtcc.org/2013/09/01/eu-faces-dilemma-as-aviation-climate-deal-stays-grounded/

[11] IATA https://www.iata.org/pressroom/Documents/iata-letter-austria-chancellor-nov2010.pdf

[12] VV.AA. (2012) Civil Aviation Authority. Aviation's Impact on Climate Change. http://www.caa.co.uk/default.aspx?catid=2921\&pagetype=90\&pageid=16558

[13] ATAG (2014) Aviation Benefits beyond Borders. Introduction, 6.

[14] VV.AA. http://www.statista.com/statistics/278372/revenue-of-commercial-airlines-worldwide/

[15] IATA https://www.iata.org/pressroom/facts_figures/fact_sheets/Documents/industry-facts.pdf

[16] The Economist (2014) Why Airlines Make Such Meagre Profits. http://www.economist.com/blogs/economist-explains/2014/02/economist-explains-5

[17] US Environmental Protection Agency (2011) Inventory of U.S. Greenhouse Gas Emissions and Sinks: 1990-2009, 26. http://www.epa.gov/climatechange/Downloads/ghgemissions/US-GHG-Inventory-2011-Complete Report.pdf.

[18] Metz, B., et al. (2007) Technical Summary. In: Climate Change Mitigation. Contribution of Working Group III to the Fourth Assessment Report of the Intergovernmental Panel on Climate Change, Cambridge University Press, Cambridge, United Kingdom and New York, USA, 3.

[19] Leggett, J.A., Elias, B. and Shedd, D.T. (2012) Aviation and the European Union Emission Trading Scheme. Congressional Research Service, 9.

[20] Vhma, A. and Van Assel, H. (2014) The Conflict over Aviation Emissions: A Case of Retreating EU leadership? FII A Briefing Paper 150, 3.

[21] Congressional Research Service (2011) Aviation and the European Union Emission Trading Scheme. Congressional Research Service, CRS Figure Using Data from IEA C02 Emissions Estimates, 1971-2009.

[22] Anderson, K., Bows, A. and Upham, P. (2006) Growth Scenarios for EU \& UK Aviation: Contradictions with Climate Policy. Tyndall Centre for Climate Change Research, 95. http://www.tyndall.ac.uk/sites/default/files/wp84.pdf.

[23] Anderson, K., Bows, A. and Upham, P. (2006) Growth Scenarios for EU \& UK Aviation: Contradictions with Climate Policy. Tyndall Centre for Climate Change Research, 28.

[24] Fulton, L., IEA and Eads, G., CRA (2004) IEA/SMP Model Documentation and Reference Case Projection. 10.

[25] Graichen, J. and Gugele, B. (2006) Greenhouse Gas Emissions from Aviation. ETC/ACC Technical Paper 2006/3. 
[26] Gössling, S., Broderick, J., Upham, P., Ceron, J.-P., Dubois, G., Peeters, P. and Strasdas, W. (2007) Voluntary Carbon Offsetting Schemes for Aviation: Efficiency, Credibility and Sustainable Tourism. Journal of Sustainable Tourism. 15, 223-248.

[27] Journal of Sustainable Tourism January 5, 2009 (2009) Page 227. Prepared on Data Bows et al. (2005) Explanation: The Top Line Shows the Reduction of the Total Emissions for EU25 in a Scenario of a Concentration of 550 Parts per Million by Volume (ppmv). The Middle Line Shows the Scenario with a Concentration of 450 ppmv and the Bottom Line Shows the Curve of Emissions from Aviation If a Model Is Followed without Any Intervention.

[28] ICAO (2007) Assembly Resolutions in Force. Doc 9902. Published by Authority of the Secretary General. International Appendix A. Point 1. http://www.icao.int/environmental-protection/Documents/A36_Res22.pdf

[29] InterVISTAS (2014) December 2014-World Aviation Day. http://www.intervistas.com/?p=7439

[30] http://aviationbenefits.org/social-development/tourism/

[31] ATAG (2014) Aviation Benefits beyond Borders. Introduction, 4. http://aviationbenefits.org/media/26786/ATAG_AviationBenefits2014_FULL_LowRes.pdf

[32] ATAG (2014) Aviation Benefits beyond Borders. Introduction, 40. http://aviationbenefits.org/media/26786/ATAG_AviationBenefits2014_FULL_LowRes.pdf

[33] Airports Commission-UK Government (2013) Discussion Paper 02: Aviation Connectivity and the Economy. 9. https://www.gov.uk/government/uploads/system/uploads/attachment_data/file/138162/aviation-connectivity-and-the-ec onomy.pdf

[34] http://www.statista.com/statistics/261726/countries-ranked-by-number-of-international-tourist-arrivals/

[35] World Tourism Organisation (2010) Statement Regarding Mitigation of Greenhouse Gas Emissions from Air Passenger Transport. 1. http://sdt.unwto.org/sites/all/files/docpdf/unwtoghgaviationpolicy2010.pdf

[36] Kyoto Protocol. Article 17.

[37] http://unfccc.int/meetings/copenhagen_dec_2009/items/5264.php

[38] Kyoto Protocol. Article 6:1.

[39] Government of Aragon-Spain (2009) Mercado voluntario de compensaciones de carbono. http://www.aragon.es/estaticos/ImportFiles/06/docs/\%C3\%81reas/CambioClim\%C3\%A1tico/EconomiaCarbono/merca do_voluntario_compensaciones_carbono_jul_2009.pdf

[40] http://ec.europa.eu/eu_law/introduction/what_directive_es.htm

[41] European Commission (2012) Directorate-General Climate Action. Directorate A—International and Climate Strategy. The Monitoring and Reporting Regulation-General Guidance for Aircraft Operators. 9-10. http://ec.europa.eu/clima/policies/ets/monitoring/docs/gd2 guidance aircraft en.pdf

[42] http://www.icao.int/Meetings/a38/Pages/default.aspx

[43] Decision 377/2013/EU of the European Parliament and of the Council of 24th April 2013. Whereas 6.

[44] Directive 2008/101/EC of 19 November 2008. Article 2.

[45] http://ec.europa.eu/transport/themes/strategies/doc/2011_white_paper/white-paper-illustrated-brochure_es.pdf

[46] Directive 2008/101/EC of 19 November 2008. Article 3d

[47] http://www.european-accreditation.org/

[48] https://www.gov.uk/eu-ets-monitoring-and-reporting

[49] http://www.magrama.gob.es/es/cambio-climatico/temas/comercio-de-derechos-de-emision/INFORMACI\%C3\%93N RELATIVA_A_LOS_PS_en_tcm7-287530.pdf

[50] http://www.magrama.gob.es/es/cambio-climatico/temas/comercio-de-derechos-de-emision/14julio_asignacion_OOAA 2013-16 tcm7-338953.pdf

[51] Faber, J. and Brinke, L. (2011) The Inclusion of Aviation in the EU ETS to: Economic and Environmental Consequence. ICTDS, International Centre for Trade and Sustainable Development, 5.

[52] Faber, J. and Brinke, L. (2011) The Inclusion of Aviation in the EU ETS to: Economic and Environmental Consequence. ICTDS, International Centre for Trade and Sustainable Development, 5.

[53] IATA-Fuel Price Analysis-Current Price of Aviation Jet Fuel. http://www.iata.org/publications/economics/fuel-monitor/pages/price-analysis.aspx)ICTDS

[54] SWD (2013) 430 Final. Commission Staff Working Document .Impact Assessment, 27.

[55] SWD (2013) 430 Final. Commission Staff Working Document. Impact Assessment, 28. http://ec.europa.eu/clima/policies/transport/aviation/docs/swd_2013_430_en.pdf 
[56] Faber, J. and Brinke, L. (2011) The Inclusion of Aviation in the EU ETS to: Economic and Environmental Consequences. ICTDS, International Centre for Trade and Sustainable Development, 17.

[57] Environment Agency-U.K. (2013) European Union Emissions Trading System (EU ETS) Phase III. Guidance for Air-Craft Operators Administered by the UK. How to Comply with the EU ETS, 14. https://www.gov.uk/government/uploads/system/uploads/attachment data/file/296966/LIT 7591 32a440.pdf

[58] http://webarchive.nationalarchives.gov.uk/20140328084622/http://www.environment-agency.gov.uk/business/topics/p ollution/136058.aspx

[59] European Commission. Mobility and Transport. http://ec.europa.eu/transport/modes/air/international_aviation/country_index/united_states_en.htm

[60] Case C-366/10 ATA. http://ec.europa.eu/dgs/legal service/arrets/10c366 en.pdf

[61] European Court of Justice. Press Release, no 104/11. http://curia.europa.eu/jcms/upload/docs/application/pdf/2011-10/cp110104es.pdf

[62] The Treaty of Lisbon. Article 19. 3. b. http://register.consilium.europa.eu/doc/srv?l=EN\&f=ST\%206655\%202008\%20REV\%207

[63] Consolidated Versions of the Treaty on European Union and the Treaty on the Functioning of the European Union 2012/C 326/01, Article 252. http://eur-lex.europa.eu/legal-content/EN/TXT/HTML/?uri=CELEX:12012E/TXT\&from=ES

[64] Bonilla Sánchez, J.J. El Tribunal de Justicia de la Unión Europa. Universidad de Sevilla, Sevilla, 7. http://personal.us.es/juanbonilla/contenido/CM/LA\%20UNION\%20EUROPEA/EL\%20TRIBUNAL\%20DE\%20JUST ICIA\%20DE\%20LA\%20UNION\%20EUROPEA.pdf

[65] Opinion of Advocate General Kokott. 6 October 2011. Case C-366/10-The Air Transport Association of America and Other-(Reference for a Preliminary Ruling from the High Court of Justice of England and Wales, Queen’s Bench Division, Administrative Court (United Kingdom)). 23-24. http://ec.europa.eu/clima/news/docs/2011100601_case_c366_10_en.pdf

[66] Opinion of Advocate General Kokott. 6 October 2011. Case C-366/10-The Air Transport Association of America and Others-(Reference for a Preliminary Ruling from the High Court of Justice of England and Wales, Queen's Bench Division, Administrative Court (United Kingdom)). 8. http://ec.europa.eu/clima/news/docs/2011100601_case_c366_10_en.pdf

[67] Opinion of Advocate General Kokott. 6 October 2011. Case C-366/10-The Air Transport Association of America and Others-(Reference for a Preliminary Ruling from the High Court of Justice of England and Wales, Queen's Bench Division, Administrative Court (United Kingdom))”. 8. http://ec.europa.eu/clima/news/docs/2011100601 case c366 10 en.pdf

[68] Opinion of Advocate General Kokott. 6 October 2011. Case C-366/10-The Air Transport Association of America and Others-(Reference for a preliminary ruling from the High Court of Justice of England and Wales, Queen’s Bench Division, Administrative Court (United Kingdom)). 30. http://ec.europa.eu/clima/news/docs/2011100601_case_c366_10_en.pdf

[69] Opinion of Advocate General Kokott. 6 October 2011. Case C-366/10-The Air Transport Association of America and Others-(Reference for a preliminary ruling from the High Court of Justice of England and Wales, Queen’s Bench Division, Administrative Court (United Kingdom)). 34.

[70] Decisions. Council 2007/339/EC. Air Transport Agreement between the European Community and Its Member States, on the One Hand, and the United States of America, on the Other hand. Article 7. Application of Laws. 1. http://eur-lex.europa.eu/legal-content/EN/TXT/HTML/?uri=OJ:L:2007:134:FULL\&from=en

[71] Decisions. Council 2007/339/EC. Air Transport Agreement between the European Community and Its Member States, on the One Hand, and the United States of America, on the Other Hand. Article 15. 3. http://eur-lex.europa.eu/legal-content/EN/TXT/HTML/?uri=OJ:L:2007:134:FULL\&from=en

[72] Opinion of Advocate General Kokott. 6 October 2011. Case C-366/10-The Air Transport Association of America and Others-(Reference for a Preliminary Ruling from the High Court of Justice of England and Wales, Queen's Bench Division, Administrative Court (United Kingdom)). 47.

[73] Judgment of the Court (Grand Chamber) 21 December 2011. http://curia.europa.eu/juris/document/document.jsf?text=\&docid=117193\&pageIndex=0\&doclang=EN\&mode=req\&di $\mathrm{r}=$ \&occ=first\&part=1\&cid=246866

[74] Department of State, Washington DC, December 16, 2011. Hillary Rodham Clinton Secretary of State. Raymond H. LaHood Secretary of Transportation. http://www.nbaa.org/ops/environment/eu-ets/20111216-eu-ets-us-state-department-clinton.pdf.

[75] https://www.govtrack.us/congress/bills/112/hr2594/text 
[76] Public Law No: 112-200. https://www.congress.gov/bill/112th-congress/senate-bill/1956/text https://www.congress.gov/112/bills/s1956/BILLS-112s1956enr.pdf

[77] European Union Emissions Trading Scheme Prohibition Act of 2011. Section 4. Public Law No: 112-200. https://www.congress.gov/bill/112th-congress/senate-bill/1956/text https://www.congress.gov/112/bills/s1956/BILLS-112s1956enr.pdf

[78] Leggett, J.A., Elias, B. and Shedd, D.T. (2012) Aviation and the European Union Emission Trading Scheme. Congressional Research Service, 36.

[79] Chinese Carriers Urge Government to Retaliate for ETS. http://www.wcarn.com/news/14/14014.html

[80] Statement by the China Air Transport Association (CATA) on the EU ETS. http://www.wcarn.com/cache/news/13/13140.html

[81] Reuters. Leung, A. and Suhartono, H. (2012) China Airlines Won’t Pay EU Carbon Tax: Industry Body. http://reuters.com/article/2012/01/04/us-airlines-carbon-tax-asia-idUSTRE8030mc20120104

[82] Tunteng, V.M., Ahmad, T, von Bieberstein, K.R., Haywood, C., Bian, Y.-M., De Andrade Correa, F. and MarsolaisRicard, S. (2012) Legal Analysis on the Inclusion of Civil Aviation in the European Union Emissions Trading System. CISDL-Centre for International Sustainable Development Law 2012. 18. http://cisdl.org/public/docs/news/CISDL_EU_ETS_Expansion_Legal_Brief.pdf

[83] CATA \& Various Parties Announce Joint Statement in Fight Against EU-ETS 01. http://www.wcarn.com/news/15/15265.html

[84] http://www.upi.com/Business_News/Energy-Resources/2012/01/11/India-protest-EU-airline-emissions-tax/UPI-25031 $\underline{326279600}$

[85] (2011) A Global and Effective MBM Roadmap. ICAO Magazine, Vol. 66, nr. 3. http://www.icao.int/publications/journalsreports/2011/6603_en.pdf

[86] Assembly ICAO 38. Resolutions Adopted by the Assembly. A38-18, 95-98. http://www.icao.int/Meetings/a38/Documents/Resolutions/a38 res prov es.pdf

[87] Assembly ICAO 38. Resolutions Adopted by the Assembly. A38-18, 98-99. http://www.icao.int/Meetings/a38/Documents/Resolutions/a38_res_prov_es.pdf

[88] Ha, P.T. (2014) International Implementation of EU Emission Trading Scheme Still Unsettled. Holland \& Knight Alert. http://m.hklaw.com/News/International-Implementation-of-EU-Emission-Trading-Scheme-Still-Unsettled-10-02-2014/

[89] http://www.airportwatch.org.uk/2014/01/more-problems-for-aviation-in-the-eu-ets-as-france-and-germany-will-not-enf orce-sanctions-for-non-compliance/

[90] UNWTO (United Nations World Tourism Organisation) (2012) Global Report on Aviation. 10. http://www.everis.com/global/WCLibraryRepository/References/tourism_study.pdf

[91] http://aviationbenefits.org/social-development/tourism/

[92] UNWTO (United Nations World Tourism Organisation) (2012) Global Report on Aviation. 12. http://www.everis.com/global/WCLibraryRepository/References/tourism_study.pdf

[93] UNWTO (United Nations World Tourism Organisation) (2012) Global Report on Aviation. 46. http://www.everis.com/global/WCLibraryRepository/References/tourism study.pdf

[94] UNWTO Climate Change and Tourism. http://sdt.unwto.org/en/content/climate-change-tourism

[95] Faber, J. and Brinke, L. (2011) The Inclusion of Aviation in to the EU ETS: Economic and Environmental Consequences. ICTDS, International Centre for Trade and Sustainable Development, 6.

[96] http://aviationbenefits.org/social-development/tourism/

[97] Cordonier, K.A. and Segger, M.C. (2002) The Principle of Common but Differentiated Responsibilities: Origins and Scope. The Centre for International Sustainable Development Law (CISDL). http://cisdl.org/public/docs/news/brief_common.pdf

[98] http://ec.europa.eu/clima/policies/roadmap/index_en.htm

[99] Ulmann, L. (2014) The European Files-Energy and Climate, What Strategies for Europe Magazine. European Commission, 3.

[100] http://ec.europa.eu/clima/policies/roadmap/index_en.htm

[101] http://www.statista.com/statistics/261726/countries-ranked-by-number-of-international-tourist-arrivals/

[102] http://www.statista.com/statistics/269617/top-10-airlines-worldwide-by-number-of-passengers/ 